\title{
Single-cell phenotypic characterization of human pituitary GHomas and non-functioning adenomas based on hormone content and calcium responses to hypothalamic releasing hormones
}

\section{OPEN ACCESS}

Edited by:

Ala-Eddin Al Moustafa,

McGill and Concordia Universities,

Canada;

Syrian Research Cancer Center of the Syrian Society Against Cancer, Syria

Reviewed by:

Yongmei Song,

Chinese Academy of Medical

Sciences, China

Hunain Alam,

University of Texas MD Anderson

Cancer Center, USA

${ }^{*}$ Correspondence:

Carlos Villalobos,

Instituto de Biología y Genética Molecular (IBGM), CSIC, c/Sanz y

Forés 3, Valladolid 47003, Spain carlosv@ibgm.uva.es

Specialty section:

This article was submitted to Molecular and Cellular Oncology,

a section of the journal

Frontiers in Oncology

Received: 20 March 2015

Accepted: 18 May 2015

Published: 09 June 2015

Citation:

Senovilla L, Núñez L, de Campos JM, de Luis DA, Romero E, García-Sancho J and Villalobos $C$

(2015) Single-cell phenotypic characterization of human pituitary

GHomas and non-functioning

adenomas based on hormone content and calcium responses to hypothalamic releasing hormones.

Front. Oncol. 5:124.

doi: 10.3389/fonc.2015.00124

\author{
Laura Senovilla ${ }^{1}$, Lucía Núñez ${ }^{1,2}$, José María de Campos ${ }^{3}$, Daniel A. de Luis ${ }^{4}$, \\ Enrique Romero ${ }^{4}$, Javier García-Sancho ${ }^{1,2}$ and Carlos Villalobos ${ }^{1 *}$
}

${ }^{1}$ Instituto de Biología y Genética Molecular (IBGM), CSIC, Valladolid, Spain, ${ }^{2}$ Departamento de Bioquímica y Biología Molecular y Fisiología, Universidad de Valladolid, Valladolid, Spain, ${ }^{3}$ Hospital Universitario Del Río Hortega (HURH), Valladolid, Spain, ${ }^{4}$ Departamento de Endocrinología y Nutrición, Hospital Clínico Universitario e Instituto de Endocrinología y Nutrición, Universidad de Valladolid, Valladolid, Spain

Human pituitary tumors are generally benign adenomas causing considerable morbidity due to excess hormone secretion, hypopituitarism, and other tumor mass effects. Pituitary tumors are highly heterogeneous and difficult to type, often containing mixed cell phenotypes. We have used calcium imaging followed by multiple immunocytochemistry to type growth hormone secreting (GHomas) and non-functioning pituitary adenomas (NFPAs). Individual cells were typed for stored hormones and calcium responses to classic hypothalamic releasing hormones $(\mathrm{HRHs})$. We found that GHomas contained growth hormone cells either lacking responses to HRHs or responding to all four HRHs. However, most GHoma cells were polyhormonal cells responsive to both thyrotropin-releasing hormone $(\mathrm{TRH})$ and $\mathrm{GH}$-releasing hormone. NFPAs were also highly heterogeneous. Some of them contained ACTH cells lacking responses to HRHs or polyhormonal gonadotropes responsive to LHRH and TRH. However, most NFPAs were made of cells storing no hormone and responded only to $\mathrm{TRH}$. These results may provide new insights on the ontogeny of GHomas and NFPAs.

Keywords: pituitary adenomas, GHomas, somatotropinomas, non-functioning pituitary adenomas, hypothalamic releasing factors, calcium imaging

\section{Introduction}

Pituitary adenomas are non-metastasizing neoplasms of adenohypophyseal cells occurring with an incidence extrapolated from autopsies larger than $20 \%$. In addition, common mutations of oncogenes and tumor suppressor genes present in non-endocrine neoplasms, such as PKC, RAS, P53 and RB, are usually absent in pituitary adenomas. Multiple evidence indicate that pituitary tumors are monoclonal in nature (1) suggesting five well-defined types of pituitary adenomas $(1,2)$. Pituitary tumors are classically typed according to morphometric and secretory characteristics (3). For example, pituitary tumors secreting growth hormone (GH), called also GHomas or somatotropinomas, represent about $15 \%$ of all pituitary tumors detected (4). They are 
characterized by excess of GH secretion causing acromegaly in adults and gigantism in children. Other frequent pituitary tumors are the non-functioning pituitary adenomas (NFPAs) representing around $20 \%$ of all pituitary adenomas. These mostly benign adenomas include null cell adenomas, gonadotroph adenomas staining but not releasing gonadotropins, and silent adenomas resembling silent corticogonadotroph adenomas (5). These patients suffer of tumor mass effects including headache, visual disturbances, and hypopituitarism and are usually diagnosed as macroadenomas after magnetic resonance imaging (MRI).

According to the monoclonal hypothesis, cells from $\mathrm{GH}$-secreting tumors should express functional receptors for $\mathrm{GH}$-releasing hormone $(\mathrm{GHRH})$ and store and release $\mathrm{GH}$. However, paradoxical secretion of alternative anterior pituitary (AP) hormones has been reported in multiple instances of pituitary adenoma, including GHoma patients responding to thyrotropin-releasing hormone (TRH) with GH secretion (6-9) and acromegaly patients producing prolactin (PRL) upon GHRH administration (10). Paradoxical secretion has been also noticed in normal pituitary glands, both in vitro and in vivo $(11,12)$. These data suggest that pituitary tumors may comprise cells expressing multiple AP hormones. Consistently, AP cells co-storing thyroidstimulating hormone (TSH) and GH or PRL (13) have been reported. Multihormonal tumor cells producing GH and TSH have been isolated from patients affected by acromegaly and hyperthyroidism (14) and cells co-secreting GH and PRL have been described in pituitary adenomas from acromegalics (15). Additionally, mRNA for both GH and PRL has been detected in the tumors of patients with a clinical diagnosis of acromegaly or gigantism (16).

We have previously shown that a series of human pituitary adenomas including prolactinomas, pituitary adenomas associated to multiple endocrine neoplasia type I (MEN I) disease, pituitary tumors linked to Cushing's disease, and a few NFPA contained indeed cells storing more than one AP hormone (multihormonal cells) and/or showing responses to more than one hypothalamic releasing hormone (HRH) (multiresponsive cells) (17). For this end, we used fluorescence imaging of individual cells loaded with fura2 to record the rises in cytosolic $\mathrm{Ca}^{2+}$ concentration $\left(\left[\mathrm{Ca}^{2+}\right]_{\text {cyt }}\right.$ ) induced by specific HRHs added and removed sequentially. It is well established that stimulation of each of the four classic HRH receptors induced a rise in $\left[\mathrm{Ca}^{2+}\right]_{c y t}$, in specific cell subpopulations, thus providing functional evidence of expression of specific $\mathrm{HRH}$ receptors in individual cells. Combination of this approach to multiple immunocytochemistry in the very same cells used for calcium imaging provides the advantage of characterizing the hormones stored and the functional $\mathrm{HRH}$ receptors expressed at the single-cell level $(17,18)$.

However, the number of NFPA studied in our former study was very too low and no data were obtained from GHomas. Accordingly, we aimed here at characterizing the phenotype of individual cells from human GHomas and additional NFPAs according to the hormones stored and functional (calcium) responses to the four classic HRHs including TRH, GHRH, corticotrophin-releasing hormone $(\mathrm{CRH})$, and gonadotropin-releasing hormone. For this end, we used a combination of multiple immunofluorescence and calcium imaging applied on the same individual cells reported previously $(17,18)$.

\section{Materials and Methods}

\section{Materials}

Antisera against human AP hormones FSH $\beta$ (AFP 891891), GH (AFPC11981A), LHß (AFP55951889), PRL (AFP55781789), TSH $\beta$ (AFP55741789), and ACTH (AFP39032082Rb) were generous gifts from the National Hormone and Pituitary Program (Torrance, CA, USA) and Dr. A. F. Parlow. Human HRHs (GHRH, TRH, LHRH, and CRH) were purchased from Sigma (Madrid, Spain). Fluorescent antibodies were prepared by labeling with Oregon Green 488, Cascade Yellow, or Alexa 350 and purified over a protein A-Sepharose column (17). Fura-2/AM, Oregon Green 488-isothiocyanate, Cascade Yellow succinimidyl ester, and Alexa 350 succinimidyl ester were purchased from Molecular Probes (Eugene, OR, USA).

\section{Human Pituitary Tumor Cell Culture}

All the procedures used here were approved by the Valladolid University Hospital and the Valladolid University School of Medicine ethical committees. Selected patients were asked to sign an informed consent form. Fresh pituitary tumor tissue was obtained at the time of surgery and quickly carried to the laboratory in cold minimal essential medium (MEM, Invitrogen, Carlsbad, CA, USA). Extreme care was taken to ensure that samples used for cell culture were devoid of any contaminating normal tissue. Tissue was transferred to fresh MEM medium at room temperature, washed extensively with the same medium and quickly dispersed with trypsin $(1 \mathrm{mg} / \mathrm{ml})$ for $15-30 \mathrm{~min}$ at $37^{\circ} \mathrm{C}$. Dispersed cells washed twice, plated onto coverslips previously coated with $0.01 \mathrm{mg} / \mathrm{ml}$ poly-L-lysine and cultured in Dulbecco's modified Eagle's Medium (DMEM, Invitrogen) supplemented with 10\% fetal bovine serum and antibiotics for at least $2 \mathrm{~h}$ for recovery. Further details have been reported previously $(17,18)$.

\section{Calcium Imaging}

Calcium imaging was carried out as previously reported $(18,19)$. Briefly, after a few hours of dispersion to allow recovery from trypsin digestion, cells were incubated with Fura-2/AM $(4 \mu \mathrm{M})$ for about $1 \mathrm{~h}$ at room temperature $\left(25^{\circ} \mathrm{C}\right)$ in standard medium containing $145 \mathrm{mM} \mathrm{NaCl}, 5 \mathrm{mM} \mathrm{KCl}, 1 \mathrm{mM} \mathrm{MgCl}_{2}, 1 \mathrm{mM} \mathrm{CaCl}_{2}$, $10 \mathrm{mM}$ Hepes ( $\mathrm{pH} 7.4$ ), and $10 \mathrm{mM}$ glucose. Then, attached cells were washed in the same medium, placed in a thermostatically controlled $\left(37^{\circ} \mathrm{C}\right)$ stage of an inverted microscope (Diaphot; Nikon, Tokyo, Japan), and perfused with prewarmed standard medium. Cells were epi-illuminated alternately at 340 and $380 \mathrm{~nm}$, and light emitted above $520 \mathrm{~nm}$ was recorded using a Magical Image Processor (Applied Imaging, Newcastle, UK). Pixel-bypixel ratios of consecutive frames were obtained and cytosolic free calcium concentration $\left(\left[\mathrm{Ca}^{2+}\right]_{\mathrm{i}}\right)$ was estimated from these ratios by comparison with Fura-2/AM standards. Test solutions made of standard medium containing $10 \mathrm{nM} \mathrm{HRHs}$ were perfused for $30 \mathrm{~s}$ at the times indicated. A depolarizing solution containing $150 \mathrm{mM}$ $\mathrm{K}^{+}$(added in exchange for $\mathrm{Na}^{+}$) was perfused for $10 \mathrm{~s}$ at the end of 
the experiment to reveal healthy cells bearing functional voltageoperated $\mathrm{Ca}^{2+}$ channels. Cells not responding to the high-K ${ }^{+}$ concentration stimulus (usually $<5 \%$ of the total) were excluded from the analysis.

\section{Multiple Sequential Immunocytochemistry}

After calcium imaging, the very same studied cells were typed by the hormone/s they stored using the sequential immunocytochemistry protocol previously reported (17). Briefly, cells on the microscope's stage were carefully fixed with $4 \%$ paraformaldehyde (PFA) in PBS without losing the microscopic field. Then, cells were treated with $0.3 \%$ Triton X-100, and washed with PBS in the same conditions. After a few minutes, $10 \%$ goat serum in PBS was added. After $5 \mathrm{~min}$, cells were incubated with antibodies against three human AP hormones (TSH, FSH, and LH) labeled with Oregon Green 488, Cascade Yellow, and Alexa 350, respectively, for $30 \mathrm{~min}$. After extensive washing using the perfusion system, fluorescence images corresponding to each fluorophore were taken [Oregon Green (FSH): excitation, $490 \mathrm{~nm}$; emission, >510 nm; Cascade Yellow (TSH): excitation, $380 \mathrm{~nm}$; emission, $>510 \mathrm{~nm}$; and Alexa $350(\mathrm{LH})$ : excitation, $340 \mathrm{~nm}$; emission, >450 nm]. This step enables typing cells storing TSH, LH, or FSH as well as cells co-storing combinations of these hormones. After imaging, cells were again washed extensively using the perfusion system and incubated with a second series of antibodies against GH, PRL, and ACTH labeled with Oregon Green 488 (PRL), Cascade Yellow (GH), and Alexa 350 (ACTH) for $30 \mathrm{~min}$. Then, cells were washed, and three new fluorescence images were taken with the same fluorescence settings described above. This new image series revealed both cells that were stained by the first antibody and those labeled by the second one. Cells stained only by the second series of antibodies were identified by image subtraction. Finally, nuclei were stained with Hoechst $33258(0.5 \mu \mathrm{g} / \mathrm{ml}, 10 \mathrm{~min})$ before a last image was acquired (excitation, $340 \mathrm{~nm}$; emission, $>420 \mathrm{~nm}$ ). Further details and controls for this procedure have been reported previously $(17,18)$.

\section{Results}

\section{Strategy for Typing of Human Pituitary Adenoma Cells}

The most relevant clinical and pathological features of 9 human pituitary GHomas adenomas and 11 NFPAs used in this study are summarized in Table 1. Male and female patients were

TABLE 1 | Clinical features of the human pituitary adenomas used.

\begin{tabular}{|c|c|c|c|c|}
\hline No. & Sex, age & Clinical features & Size $(\mathrm{mm})$ & ICC \\
\hline 1 & M, 60 & Sexual dysfunction (92 nmol/I IGF-1) & 20 & $\begin{array}{l}\mathrm{GH}++ \\
\mathrm{FSH}++ \\
\mathrm{LH}++\end{array}$ \\
\hline $\begin{array}{l}2 \\
2 \text { recid }\end{array}$ & $\begin{array}{r}M, 51 \\
52\end{array}$ & Acromegaly & 35 & Unknown \\
\hline 3 & W, 45 & Acromegaly (98 nmol/I IGF-1, 40 ng/ml GH) & 10 & $\mathrm{GH}++$ \\
\hline 4 & $M, 51$ & Acromegaly (83 nmol/l IGF-1, 20 ng/ml GH, 183 mg/ml PRL) & 15 & $\begin{array}{l}\mathrm{GH}++ \\
\mathrm{PRL}++\end{array}$ \\
\hline 5 & W, 66 & Acromegaly (84 nmol/I IGF-1) & 5 & $\mathrm{GH}+++$ \\
\hline 6 & W, 65 & Acromegaly & 30 & Unknown \\
\hline 7 & M, 28 & Acromegaly & 20 & Unknown \\
\hline 8 & W, 52 & Acromegaly (84 nmol// IGF-1) & Invasive & $\begin{array}{l}\mathrm{GH}++ \\
\mathrm{PRL}+ \\
\mathrm{LH}+\end{array}$ \\
\hline 9 & $M, 45$ & Non-functioning, visual defects, headache, low TSH, LH, and testosterone & 35 & $\mathrm{ACTH}++$ \\
\hline 10 & W, 55 & Non-functioning, visual defects, low TSH, and LH & 40 & $\mathrm{FSH}+++$ \\
\hline 11 & M, 76 & Non-functioning, hypopituitarism (8years) & 30 & $\mathrm{ACTH}+$ \\
\hline 12 & W, 37 & Non-functioning, hyperprolactinemia (40 ng/ml PRL), amenorrhea, galactorrhea & 12 & Negative \\
\hline 13 & M, 59 & Non-functioning, hypopituitarism & 23 & $\mathrm{FSH}+$ \\
\hline 14 & W, 53 & Non-functioning, visual defects & 29 & $\mathrm{ACTH}+$ \\
\hline 15 & M, 39 & Non-functioning, visual defects, headache, cortisol 8 a.m. 24 g/dl, ACTH a.m. 63 pg/ml & 30 & $\mathrm{ACTH}++$ \\
\hline 16 & W, 75 & Non-functioning, low thyroid hormones & 35 & Unknown \\
\hline 17 & W, 57 & Non-functioning, visual defects, low GH, and LH, ACTH a.m. 80 pg/ml & 40 & Unknown \\
\hline 18 & M, 67 & Non-functioning, visual defects, hypopituitarism & 30 & Unknown \\
\hline 19 & W, 60 & Non-functioning, visual defects, hypopituitarism & 30 & $\begin{array}{l}\mathrm{LH}++ \\
\mathrm{FSH}+ \\
\mathrm{PRL}+\end{array}$ \\
\hline
\end{tabular}


45-66 years old and selected because they were clinically diagnosed of either acromegaly or NFPA before being subjected to neurosurgery for adenoma ablation. In the case of GHomas, three adenomas out of five that had been studied by immunohistochemistry at the pathology department stained positive for $\mathrm{GH}$ and another hormone, supporting the status of "paradoxically secreting tumors." Paradoxical secretion was suspected, for instance, in patient \#4, who presented increased serum levels of PRL. Experiments were conducted to study functional responses to the four classic HRHs and multiple sequential immunocytochemistry (MSPI) for testing single or multiple AP hormone content in the same, individual cells.

Figure 1 summarizes the strategy followed for the phenotypic characterization of pituitary adenoma cells, which was established first in mouse AP cells (18) and then in other human pituitary tumors (17). Freshly dispersed pituitary tumor cells were cultured for a few hours and then loaded with fura-2/AM and subjected to calcium imaging to monitor $\mathrm{Ca}^{2+}$ responses induced by the four classic HRHs perfused sequentially (CRH, LHRH, TRH, and $\mathrm{GHRH}$ ) (Figures 1A-C). Increases in $\left[\mathrm{Ca}^{2+}\right]_{\mathrm{i}}$ in responsive cells reflects most likely expression of specific, functional HRH receptors (20-24) (Figure 1A). Responsive cells were considered those cells showing an increase in $\left[\mathrm{Ca}^{2+}\right]$ cyt larger than $50 \mathrm{nM}$ either to only a particular HRH (monoresponsive cells, Figure 1B) or to more than one HRH (multiresponsive cells, Figure 1C). At the end of the imaging experiment, cells in the same microscopic field were fixed and subjected to multiple, sequential immunocytochemistry (Figures 1D-F) against the five AP hormones to reveal content of either single or multiple AP hormones in the same cells. Based on this analysis, cells were typed as silent, monohormonal, and multihormonal depending on whether cells stored no apparent hormone, a single hormone, and several AP hormones, respectively. For instance, cells from the same tumor could stain positively for GH only of for both GH and TSH (Figure 1F).

\section{Characterization of Human GHomas}

We have used the above strategy to characterize in the first place cells derived from nine human GHomas. Most GHomas displayed distinct phenotypic characteristics, often even among cells from the same tumor. According to hormone storage and calcium responses to the four HRHs, GHomas studied here have been pooled into three different groups according to the results: Type I, non-responsive GHomas; Type II, multiresponsive GHomas, and Type III, TRH and GHRH-responsive GHomas.

Type I (non-responsive GHomas, tumors \#1, \#2, and \#3) includes tumors in which cells lacked generally responses to any $\mathrm{HRH}$ or responses were observed only in a minor fraction of cells. In fact, $<10 \%$ of cells from these tumors responded to $\mathrm{CRH}$, LHRH, TRH, and GHRH, with little or no intra-tumor differences (Figure 2A). The sequential immunocytochemical characterization in the same cells revealed some heterogeneity in terms of hormone content. Whereas tumors \#2 and \#3 contained mostly GH cells and much less frequently PRL, tumor \# 1 cells stored no hormone, although a minor fraction of cells stored FSH, PRL, and GH (Figure 2A).

Type II, multiresponsive GHomas included two tumors only, tumor recurrence \#2rec and tumor \#4. In striking contrast with

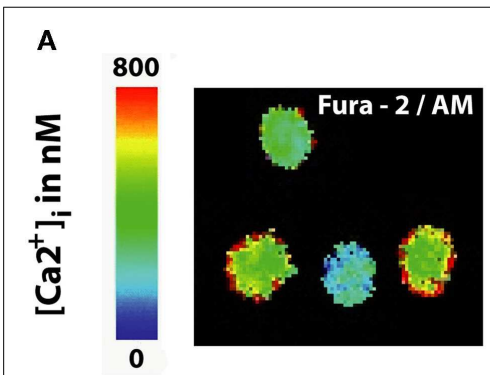

D
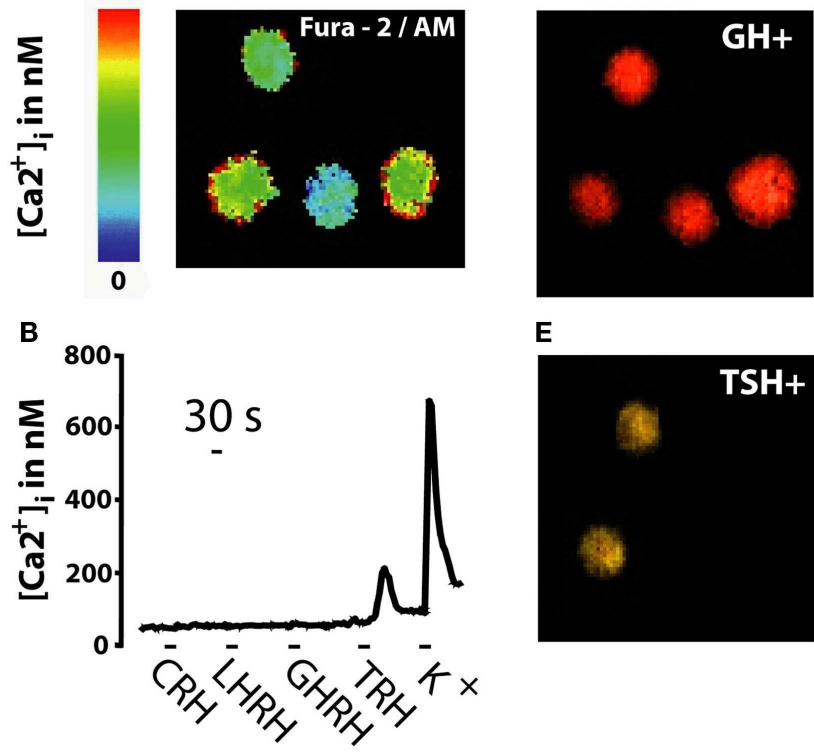

E

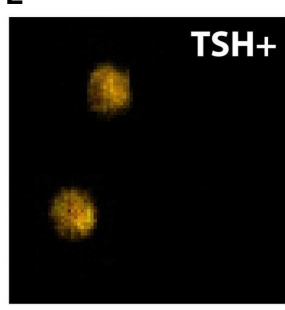

C

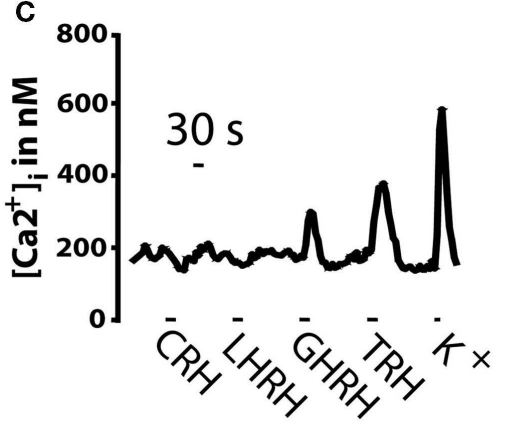

$\mathbf{F}$

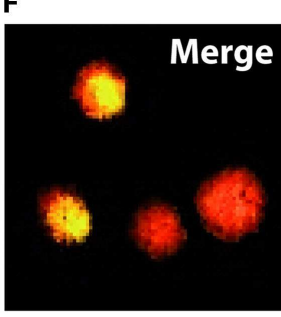

FIGURE 1 | Strategy for typing of human pituitary adenoma cells. Pituitary tumor cells were loaded with fura- 2 and subjected to $\mathrm{Ca}^{2+}$ imaging before sequential immunocytochemistry against the six AP hormones. (A) Fura2 image shows calcium levels, coded in pseudocolor $(0-800 \mathrm{nM}$, scale at left) during stimulation with $10 \mathrm{nM} \mathrm{GHRH}$. (B,C) Typical $\left[\mathrm{Ca}^{2+}\right]_{\mathrm{i}}$ recordings for two individual cells during sequential perfusion with the four $\mathrm{HRHs}(20 \mathrm{nM})$ and high- $\mathrm{K}^{+}$medium. Cells with $\left[\mathrm{Ca}^{2+}\right]_{\mathrm{i}}$ responses larger than $50 \mathrm{nM}$ were considered responsive. Cells lacking responses to high- $\mathrm{K}^{+}$were excluded from analysis. (D-F) Multiple immunocytochemistry images of the same calcium field. Cells storing $\mathrm{GH}(\mathrm{GH}+)$ are shown in red (D), cells storing $\mathrm{TSH}(\mathrm{TSH}+)$ are shown in yellow $(\mathbf{E})$ and merge image $(\mathbf{F})$ shows two monohormonal $\mathrm{GH}$ - cells (in red) and two multihormonal $\mathrm{GH}+/ \mathrm{TSH}+$ cells (in yellow). Data are representative of 547 cells studied in 21 independent experiments.

type I GHomas, nearly all individual cells in these tumors responded to all four HRHs (Figure 2B). Although there are no immunocytochemical results for tumor \#4, the patient exhibited an excessive secretion of both GH and PRL. Interestingly, the phenotype of the tumor \#2rec differed markedly from the adenoma obtained 1 year earlier from the same patient (tumor \#2). Most cells stored indeed $\mathrm{GH}$ (93\%) as did cells from the primary tumor mass $(81 \%)$. However, cells from the relapsing tumor (tumor $\# 2 \mathrm{rec}$ ) responded to HRHs much more extensively that did their primary counterparts, with more than $90 \%$ of cells responding to all tested HRHs. Therefore, the relapsing tumor studied showed a 

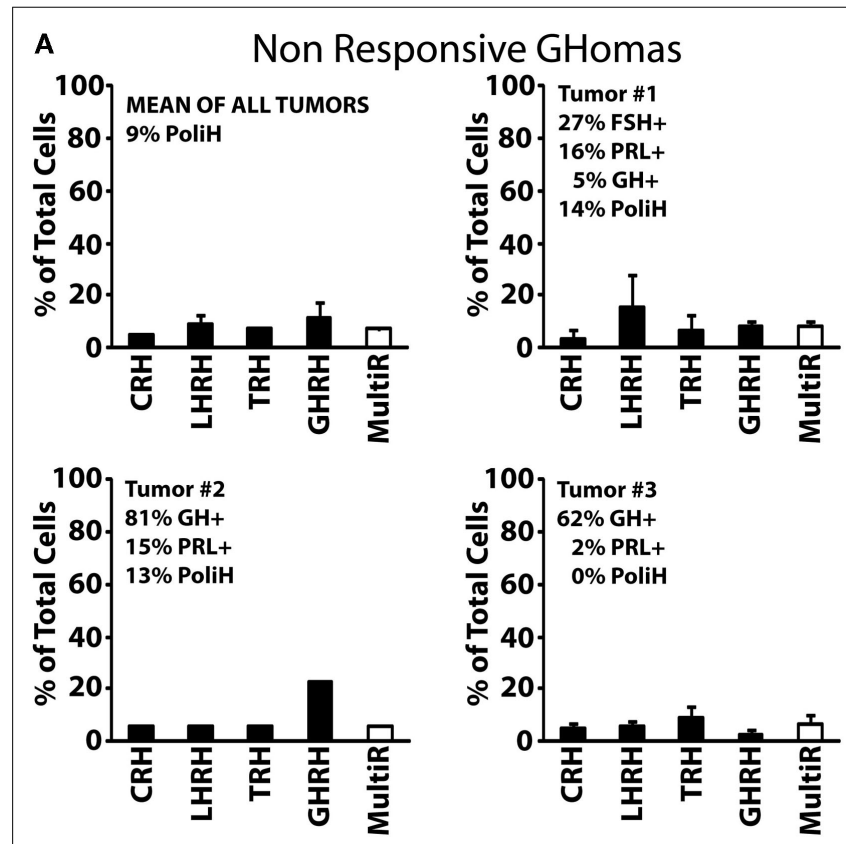

B
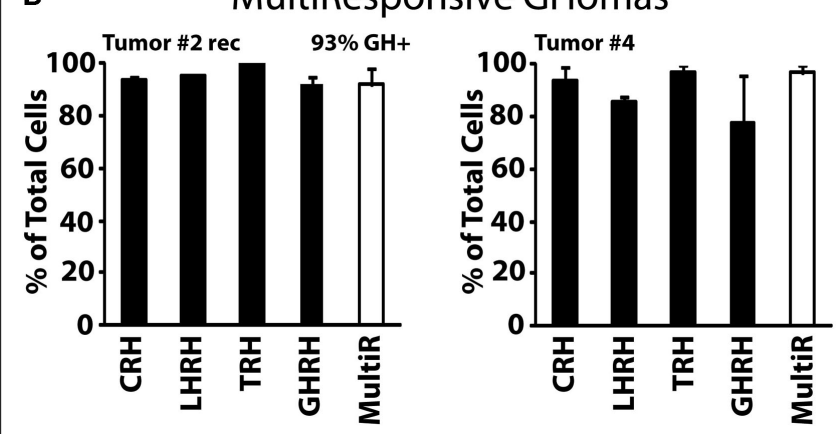

FIGURE 2 | Phenotypic characterization of non-responsive and multiresponsive GHomas. (A) The analyses of the three non-responsive tumors and their average (up graphic on the left) are shown. The percentage of cells responding to each $\mathrm{HRH}$ (with a calcium rise larger than $50 \mathrm{nM}$ ) are shown (mean \pm SEM). The white bar at right shows the percentage of multiresponsive cells (those showing responses to $>1 \mathrm{HRH}$ ). The hormonal content of the cells is given in upper right corner of each panel. Data derived from 67 cells (2 experiments, tumor \#1), 31 cells (one experiment, tumor \#2), and 198 cells (4 experiments, tumor \#3). Average data derived from 296 cells studied in 7 independent experiments. (B) Phenotypic characterization multiresponsive GHomas. Data from one tumor and one recurrence (Tumor \#2rec and \#4) are shown. Data derived from 93 cells (two experiments, \#2) and 25 cells (two experiments, tumor \#4). Clinical and pathological data of these tumors are summarized in Table $\mathbf{1 .}$

marked phenotypic contrast with the original adenoma from the same patient obtained 1 year earlier (Figure 2A).

Type III, TRH and GHRH-responsive GHomas included most (five out of nine) $\mathrm{GH}$-secreting adenomas analyzed in this study. These GHomas responded to both TRH and GHRH showing little or no response to other HRHs (Figure 3). Tumors \#5 and \#6 responded more prominently to GHRH ( $\sim 60 \%$ of the cells) than to TRH ( $~ 30-40 \%$ of the cells) but tumors \#7 and \#8 responded more frequently to TRH (with 50-60\%) than to GHRH. This group of tumors is the most heterogeneous one in terms of hormone

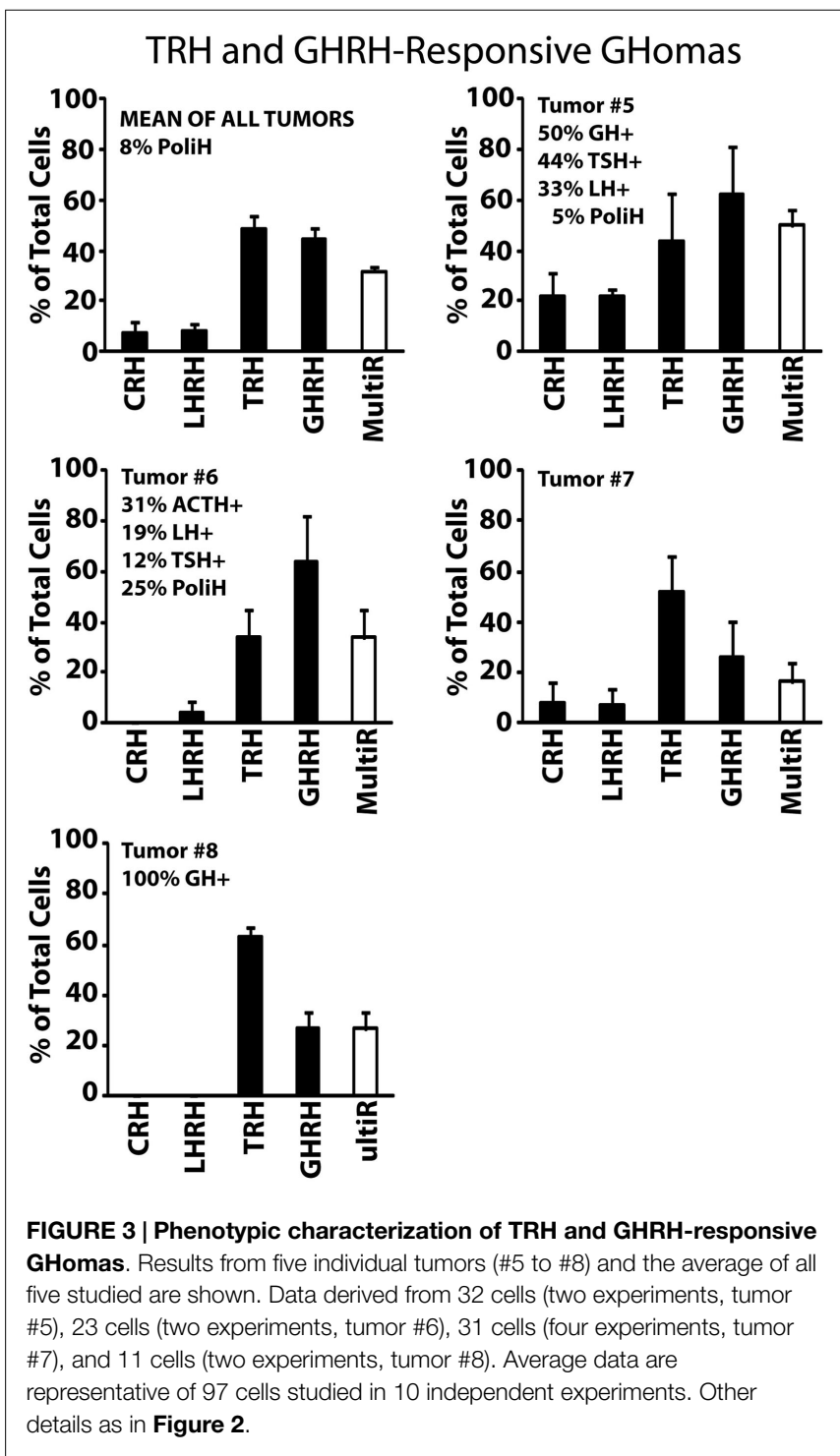

content including tumors storing multiple AP hormones. Tumor \#8 constitutes a clear example that may account for paradoxical secretion. This tumor is made of cells responding most frequently to $\mathrm{TRH}(>70 \%)$ but all cells store GH (100\%). Immunofluorescence was not performed on cultured cells from tumor \#7 owing to technical problems.

\section{Characterization of Human Non-Functioning Pituitary Adenomas}

We have characterized also individual cells derived from 11 human NFPAs. There was a large degree of functional differences among the NFPAs studied. According to hormone storage and responses to the HRHs, we have pooled also the NFPAs studied here in three different groups with distinct phenotypic characteristics: Type I, non-functioning ACTHomas; Type II, nonfunctioning gonadotropinomas, and Type III, non-functioning, null cell adenomas.

Type I, non-functioning ACTHomas includes only two tumors (Tumors \#9 and \#10). Most cells in these two adenomas stored 
ACTH. In addition, cells were either partially (\#9) or barely (\#10) sensitive to CRH. Storage of other hormones or sensitivity to additional HRH receptors was not observed (Figure 4A). Type II, non-functioning gonadotropinomas (Tumors \#11 to \#14) includes four tumors. Most cells in this group showed $\mathrm{Ca}^{2+}$ responses to TRH and $\mathrm{LHRH}$, and less frequently to GHRH. Responses to $\mathrm{CRH}$ were not observed (Figure 4B, Tumor \#14 data not shown). Hormone content was variable among adenomas but the most frequent stored hormones were gonadotropins.

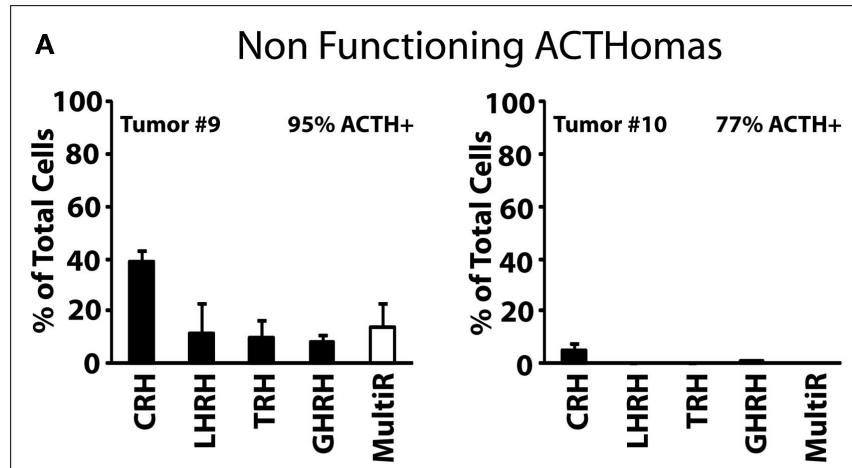

B Non Functioning Gonadotropinomas
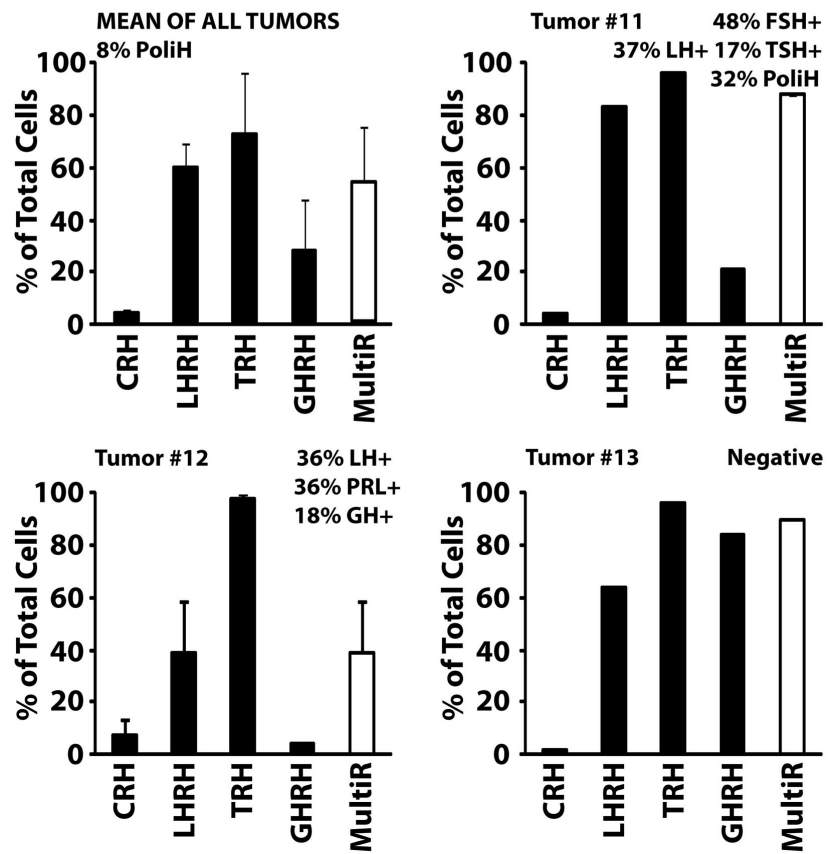

FIGURE 4 | Phenotypic characterization of non-functioning pituitary adenomas (NFPAs) with ACTH immunopositivity. (A) Analyses of two NFPA are shown. Percents of cells responding to each $\mathrm{HRH}$ with a calcium rise larger than $50 \mathrm{nM}$ are shown. The white bar at right shows the percentage of multiresponsive cells (those showing responses to $>1 \mathrm{HRH}$ ). Data derived from 24 cells ( 2 experiments, tumor \#9) and 188 cells ( 2 experiment, tumor \#10). (B) Data from four tumors (\#11, \#12, and \#13) and average are shown. Tumor \#14 was made of cells responding (50\%) to LHRH but not to any other $\mathrm{HRH}$. About $25 \%$ of cells in this tumor stored either FSH or LH (not shown). Data derived from 139 cells (1 experiment, tumor \#11), 38 cells (2 experiments, tumor \#12), 50 cells (1 experiment, tumor \#13), and 32 cells (2 experiments tumor \#14). Average data are representative of 259 cells studied in 4 independent experiments. Other details as in Figure 2.
Interestingly, gonadotropins were co-stored with additional AP hormones including TSH, PRL, GH, and even ACTH. The overall fraction of multiresponsive cells was as high as $70 \%$ of the cells. Finally, type III, non-functioning null cell adenomas included the most abundant group (5 out of 11) of NFPAs tested here. These adenomas showed a very homogeneous phenotype strikingly different from the previous ones. In the five tumors studied (\#15 to \#19), all the cells showed strong responses to TRH but not to any other HRH. Regarding hormone storage, all adenomas stored apparently no hormone except one that stored mostly TSH and FSH with a lower fraction of cells storing GH (Figure 5).

\section{Discussion}

The pituitary gland is considered the master gland in charge of the endocrine system. Input from the hypothalamus in the form

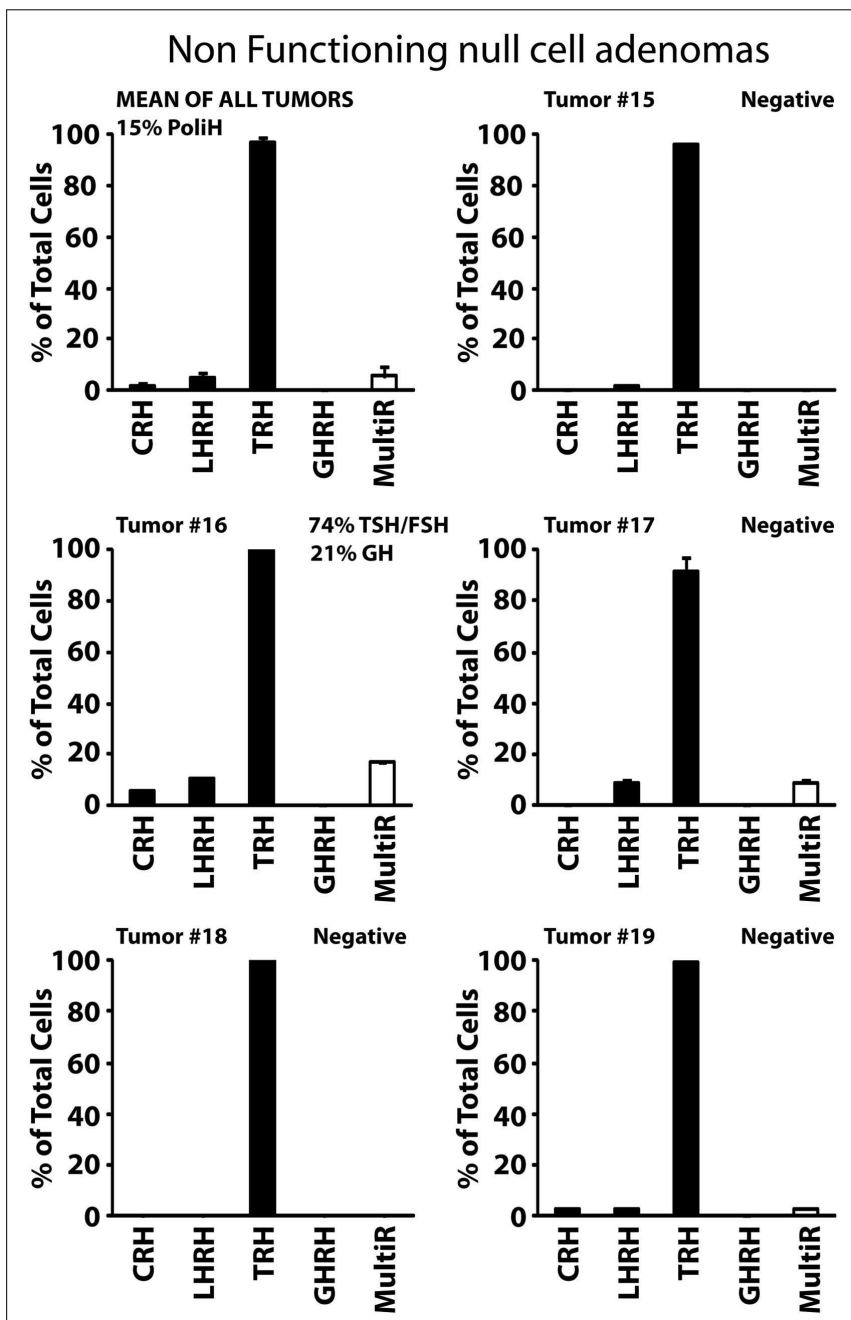

FIGURE 5 | Phenotypic characterization of non-functioning, null cell adenomas. Results from five individual tumors (\#15 to \#19) and the average of all five studied are shown. Data derived from 54 cells (1 experiment, tumor \#15), 19 cells (1 experiment, tumor \#16), 22 cells (2 experiments, tumor \#17), 27 cells (2 experiments, tumor \#18), and 96 cells (2 experiments, tumor \#19). Average data are representative of 218 cells studied in 8 independent experiments. Other details as in Figure 2. 
of hypothalamic releasing (and inhibiting) factors controls the release of specific AP hormones. AP hormones, in turn, modulate the activity of downstream peripheral glands and tissues that feedback at both hypothalamic and pituitary levels. Although pituitary tumors are generally benign and do not form metastasis, they have usually a strong impact on patient's health due to chronic hormone imbalances and/or tumor mass effects. Pituitary tumors are typically characterized by its large heterogeneity. This is expected to some extent since the AP is made of five different cell types characterized by storage of different AP hormones and sensitivity to different hypothalamic releasing and inhibiting factors. However, classification of pituitary tumors is highly controversial. To improve tumor typing and gain insights on pituitary adenoma ontogeny, we have characterized hundreds of individual cells from a series of twenty human pituitary tumors classified clinically as GHomas and NFPAs, two categories that comprise nearly $40 \%$ of all pituitary tumors. The single-cell phenotypes of other frequent pituitary adenomas including prolactinomas, adenomas related to MEN-1 and Cushing, and a few NFPAs has been reported previously (17).

We found that most GHomas were made of polyhormonal cells storing $\mathrm{GH}$ and showing calcium responses to both TRH and GHRH (type III GHomas). Other GHomas stored only $\mathrm{GH}$ but responded to all four HRH (type II GHomas) or were polyhormonal cells lacking responses to any HRH (type I GHomas). The presence of multifunctional cells (multiresponsive and/or polyhormonal cells) in human GHomas may explain, in a simple way, the occurrence of paradoxical secretion, which has been frequently reported in pituitary tumors (6-13). Consistently, the most common phenotype of GHomas made of polyhormonal GH cells and showing responses to both TRH and GHRH may explain paradoxical secretion of $\mathrm{GH}$ induced by several HRHs, most notably TRH. In addition, it may also explain paradoxical secretion of other AP hormones by GHomas. No information is available on single-cell phenotypes in the human, normal AP. Several attempts have been carried out in samples from organ donors but cell cultures have failed so far in our hands. However, normal GH cells from mice are mostly monohormonal cells responding only to GHRH $(18,25)$ and the multifunctional phenotype seem to show up only in demanding physiological situations, a process that has been related to pituitary plasticity. Accordingly, the abundance of multifunctional phenotypes in human GHomas suggests that adenomas may arise as a consequence of dysfunctional pituitary plasticity as suggested previously for other pituitary adenomas (17).

Regarding NFPAS, we found that a large fraction of NFPAs studied were made of cells holding a very particular phenotype: These cells are rather homogenous, store no detectable hormone (null cells) and responded only to TRH (type III nonfunctioning adenomas). Other NFPAs contained polyhormonal gonadotropes responding to LHRH and TRH (type II nonfunctioning adenomas) or monohormonal corticotropes lacking responses to HRHs (type I non-functioning adenomas). These results are consistent with a previous report showing that a fraction of NFPA patients show abnormal LH secretion in response to TRH (26). Accordingly, our type III and type II NFPAs may well correspond to silent gonadotrope adenomas expressing TRH receptors and differing simply in the level of expression of gonadotropins and LHRH receptors. We had previously reported a similar analysis in a small number of NFPAs (17). One of these previously reported adenomas was made of cells storing both GH and PRL reflecting probably a silent somatoprolactinoma. The other two previously reported adenomas were made of cells storing no hormone or mostly ACTH and showing responses to CRH and TRH and to a lesser extent to GHRH suggesting a corticotrope ontogeny. Accordingly, the two previously reported NFPAs resemble the type 1 NFPA reported here.

Hypothalamic releasing hormones are considered more than simple secretagogues as they are also able to promote proliferation of target cells. For example, it has been reported that excessive secretion of GHRH or overexpression of GHRH receptors may result in deregulated proliferation of somatotrophs, leading to hyperplasia, and neoplastic transformation (27). Interestingly, a large fraction of GHomas and most NFPAs studied responded largely to TRH either alone or in combination with other HRHs. If confirmed, these results suggest that TRH antagonists could be considered for the treatment of a large fraction of NFPAs. This could be particularly interesting for type III NFPAs accounting for about $50 \%$ of all NFPAs studied here as they are responsive only to TRH but not to any other HRHS. According to our results, this possible treatment could be less effective for type II NFPAs as they are responsive also to LHRH and GHRH. No effect of TRH antagonists is expected in type I NFPAs as they lack calcium responses to TRH. However, in this particular case, a possible effect of CRH antagonists is expected as cells from these tumors respond to $\mathrm{CRH}$ but not to any other HRH. Further research is required to confirm these results and to validate $\mathrm{TRH}$ and $\mathrm{CRH}$ receptors as targets for NFPAS.

Finally, it has been previously suggested that cell phenotypes within the normal AP are not static $(25,28)$. Instead, they are moving targets that may undergo dramatic changes in demanding physiological situations such as maturation, puberty, and senescence (29). It is worth noting that even a short period of stress may lead to significant changes in AP cell composition, particularly in females (30). One interesting possibility is that this plasticity, a particular characteristic of AP cells, may remain in the tumor and be activated by extrinsic factors, thus providing an explanation for changes in cell phenotypes in tumor recurrences. This plasticity may also contribute to explain phenotypic differences among cells within the same tumor. Further research is required to understand phenotypic heterogeneity and plasticity in the AP and pituitary adenomas.

\section{Acknowledgments}

We thank grant support from Instituto de Salud Carlos III (FIS03/1231), Spain and Ministerio de Economia y Competitividad (ref. BFU2012-37146), Spain. This paper is dedicated to the memory of Dr. José María de Campos. 


\section{References}

1. Melmed S. Pathogenesis of pituitary tumors. Endocrinol Metab Clin North Am (1999) 28(1):1-12. doi:10.1016/S0889-8529(05)70055-4

2. Herman V, Fagin J, Gonsky R, Kovacs K, Melmed S. Clonal origin of pituitary adenomas. J Clin Endocrinol Metab (1990) 71(6):1427-33. doi:10.1210/ jcem-71-6-1427

3. Kovacs K, Horvath E, Vidal S. Classification of pituitary adenomas. J Neurooncol (2001) 54(2):121-7. doi:10.1023/A:1012945129981

4. Asa SL, Ezzat S. The cytogenesis and pathogenesis of pituitary adenomas. Endocr Rev (1998) 19(6):798-827. doi:10.1210/edrv.19.6.0350

5. Cooper O, Ben-Shlomo A, Bonert V, Bannykh S, Mirocha J, Melmed S. Silent corticogonadotrophs adenomas: clinical and cellular characteristics and long-term outcomes. Horm Cancer (2010) 1(2):80-92. doi:10.1007/ s12672-010-0014-x

6. Hanew K, Aida M, Sasaki A, Mouri T, Yoshinaga K. Abnormal growth hormone responses to CB-154 and thyrotropin-releasing hormone (TRH) in patients with acromegaly. Tohoku J Exp Med (1979) 127(1):53-62. doi:10.1620/tjem.127.53

7. De Marinis L, Mancini A, Zuppi P, Anile C, Maira G. Paradoxical growth hormone response to thyrotropin-releasing hormone in acromegaly. Clinical correlations and prognostic value. Acta Endocrinol (Copenh) (1990) 22(4):443-9.

8. Bando H, Sano T, Ohshima T, Zhang CY, Yamasaki R, Matsumoto K, et al. Differences in pathological findings and growth hormone responses in patients with growth hormone-producing pituitary adenoma. Endocrinol Jpn (1992) 39(4):355-63. doi:10.1507/endocrj1954.39.355

9. Okinaga H, Takano K, Hayashi S, Yasufuku-Takano J, Teramoto A, Fujita T. Mechanisms of TRH-induced GH release (paradoxical response) in human somatotroph adenoma cells. Endocr J (2005) 52(6):763-7. doi:10.1507/endocrj. 52.763

10. Losa M, Schopohl J, Müller OA, von Werder K. Growth hormone releasing factor induces prolactin secretion in acromegalic patients but not in normal subjects. Acta Endocrinol (Copenh) (1985) 109(4):467-73.

11. Amsterdam JD, Winokur A, Lucki I, Snyder P, Harris RI, Caroff S, et al. Growth hormone, prolactin and thyrotropin responses to gonadotropin-releasing hormone in depressed patients and healthy volunteers. Psychoneuroendocrinology (1982) 7(2-3):177-84. doi:10.1016/0306-4530(82)90010-5

12. Fischer UG, Wood SH, Bruhn J, Roseff SJ, Mortola J, Rivier JE, et al. Effect of human corticotropin-releasing hormone on gonadotropin secretion in cycling and postmenopausal women. Fertil Steril (1992) 58(6):1108-12.

13. Vidal S, Syro L, Horvath E, Uribe H, Kovacs K. Ultrastructural and immunoelectron microscopic study of three unusual plurihormonal pituitary adenomas. Ultrastruct Pathol (1999) 23(3):141-8. doi:10.1080/019131299281635

14. Malarkey WB, Kovacs K, O'Dorisio TM. Response of a GH- and TSH-secreting pituitary adenoma to a somatostatin analogue (SMS 201-995): evidence that GH and TSH coexist in the same cell and secretory granules. Neuroendocrinology (1989) 49(3):267-74. doi:10.1159/000125127

15. Corenblum B, Sirek AM, Horvath E, Kovacs K, Ezrin C. Human mixed somatotrophic and lactotrophic pituitary adenomas. J Clin Endocrinol Metab (1976) 42(5):857-63. doi:10.1210/jcem-42-5-857

16. Lloyd RV, Cano M, Chandler WF, Barkan AL, Horvath E, Kovacs K. Human growth hormone and prolactin secreting pituitary adenomas analyzed by in situ hybridization. Am J Pathol (1989) 134(3):605-13.

17. Senovilla L, Núñez L, de Campos JM, de Luis DA, Romero E, Sánchez A, et al. Multifunctional cells in human pituitary adenomas: implications for paradoxical secretion and tumorigenesis. J Clin Endocrinol Metab (2004) 89(9):4545-52. doi:10.1210/jc.2004-0072
18. Núñez L, Villalobos C, Senovilla L, García-Sancho J. Multifunctional cells of mouse anterior pituitary reveal a striking sexual dimorphism. J Physiol (Lond) (2003) 549(3):835-43. doi:10.1113/jphysiol.2003.040758

19. Villalobos C, Núñez L, Frawley LS, García-Sancho J, Sánchez A. Multiresponsiveness of single anterior pituitary cells to hypothalamic releasing hormones: a cellular basis for paradoxical secretion. Proc Natl Acad Sci U S A (1997) 94(25):14132-7. doi:10.1073/pnas.94.25.14132

20. Cuttler L, Glaum SR, Collins BA, Miller RJ. Calcium signalling in single growth hormone-releasing factor-responsive pituitary cells. Endocrinology (1992) 130(2):945-53. doi:10.1210/endo.130.2.1733736

21. Tse A, Hille B. GnRH-induced $\mathrm{Ca}^{2+}$ oscillations and rhythmic hyperpolarizations of pituitary gonadotropes. Science (1992) 255(5043):462-4. doi:10.1126/ science. 1734523

22. Ashworth R, Hinkle PM. Thyrotropin-releasing hormone-induced intracellular calcium responses in individual rat lactotrophs and thyrotrophs. Endocrinology (1996) 137(12):5205-12. doi:10.1210/endo.137.12.8940336

23. Villalobos C, Núñez L, García-Sancho J. Functional glutamate receptors in a subpopulation of anterior pituitary cells. FASEB J (1996) 10(5):654-60.

24. Shorten PR, Robson AB, McKinnon AE, Wall DJ. CRH-induced electrical activity and calcium signalling in pituitary corticotrophs. J Theor Biol (2000) 206(3):395-405. doi:10.1006/jtbi.2000.2135

25. Villalobos C, Núñez L, García-Sancho J. Phenotypic characterization of multifunctional somatotropes, mammotropes and gonadotropes of the mouse anterior pituitary. Pflügers Arch (2004) 449(3):257-64. doi:10.1007/ s00424-004-1337-7

26. Gil-del-Alamo P, Pettersson KS, Saccomanno K, Spada A, Faglia G, BeckPeccoz P. Abnormal response of luteinizing hormone beta subunit to thyrotrophin-releasing hormone in patients with non-functioning pituitary adenoma. Clin Endocrinol (Oxf) (1994) 41(5):661-6. doi:10.1111/j.1365-2265. 1994.tb01833.x

27. Frohman LA, Kineman RD. Growth hormone-releasing hormone and pituitary development, hyperplasia and tumorigenesis. Trends Endocrinol Metab (2002) 13(7):299-303. doi:10.1016/S1043-2760(02)00613-6

28. Villalobos C, Núñez L, García-Sancho J. Anterior pituitary thyrotropes are multifunctional cells. Am J Physiol (2004) 287(6):E1166-70. doi:10.1152/ajpendo. 00194.2004

29. Senovilla L, García-Sancho J, Villalobos C. Changes in expression of hypothalamic releasing hormone receptors in individual rat anterior pituitary cells during maturation, puberty and senescence. Endocrinology (2005) 146(11):4627-34. doi:10.1210/en.2005-0836

30. Senovilla L, Núñez L, Villalobos C, García-Sancho J. Rapid changes in anterior pituitary cell phenotypes in male and female mice after acute cold stress. Endocrinology (2008) 149(5):2159-67. doi:10.1210/en.2007-1030

Conflict of Interest Statement: The authors declare that the research was conducted in the absence of any commercial or financial relationships that could be construed as a potential conflict of interest.

Copyright (c) 2015 Senovilla, Núñez, de Campos, de Luis, Romero, García-Sancho and Villalobos. This is an open-access article distributed under the terms of the Creative Commons Attribution License (CC BY). The use, distribution or reproduction in other forums is permitted, provided the original author(s) or licensor are credited and that the original publication in this journal is cited, in accordance with accepted academic practice. No use, distribution or reproduction is permitted which does not comply with these terms. 